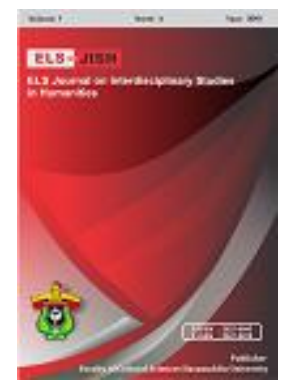

\title{
ELS-JISH
}

ELS Journal on Interdisciplinary Studies on Humanities

Volume 2 Issue 4, 2019

ISSN (print) : 2621-0843

ISSN (online) : 2621-0835

Homepage : http://journal.unhas.ac.id/index.php/jish

\section{Problems of Teaching and Learning English as a Foreign Language in South Yemen: A Case Study of Lahj Governorate}

\author{
Sabri Thabit Saleh Ahmed', Bushra Thabit Ahmed Qasem² \\ ${ }^{1}$ sabri-t2010@hotmail.com
}

\begin{abstract}
The task of teaching and learning English as a foreign language is not an easy task as there are many factors that may contribute positively or negatively to its success. In the context of this study, most school-leavers have very poor English, especially when looking at their oral skills. This indicates that there are some problems that EFL learning and teaching encounter, and then such problems are reflected in students' proficiency level. This study, therefore, explored the problems encountering EFL teaching and learning in Lahj primary and secondary schools to identify such problems and suggest some solutions that may help in improving English language teaching and learning in the concerned schools. Data were collected from 32 EFL senior teachers and supervisors of Lahj governorate. Findings showed that large classes, lack of teaching aids, teachers' low proficiency in English, teachers' limited experience with communicative language teaching, late beginning of learning English, lack of focus on oral communicative English, use of mother tongue in classroom, students' low motivation and interference between English and Arabic are considered as major problems encountering English language teaching and learning in the concerned South Yemeni schools and contribute negatively to students' proficiency level. As per the findings, the study has provided some recommendations that may help in improving EFL teaching and learning in the concerned schools and in Yemeni schools generally.
\end{abstract}

Keywords: EFL Teaching and Learning, School-leavers, Lahj primary and secondary Schools

How to cite: Ahmed, S. T. S. \& Qasem, B. T. A. (2019). Problems of Teaching and Learning English as a Foreign Language in South Yemen: A Case Study of Lahj Governorate. ELS Journal on Interdisciplinary Studies in Humanities, 2 (4), 485-492

\section{Introduction}

In recent decades, English has become a global language (Crystal, 2003) and its teaching has also become one of the most researched fields of study for EFL researchers and scholars in the field of teaching English as a second or foreign language. Researchers, scholars and teachers have attempted to find out new teaching techniques and to apply theories of linguistics, psychology and education to English classrooms to help their students to build a better communicative competence in English. There are many theories that have appeared in the second half of the last century and recommended new communicative techniques and

\footnotetext{
${ }^{1}$ Faculty member, University of Aden, Yemen \& Ph.D. scholar, Dr B.A..M. University - India

${ }^{2}$ Ph.D. scholar Dr B.A..M. University- India
} 
approaches in language teaching (Hymes, 1972; Halliday 1973; Canale \& Swain, 1980; Littlewood, 1981), with the goal of preparing students to be competent users of target language they are learning.

Producing competent users of English in Yemeni schools requires overcoming several EFL teaching and learning problems and implementing communicative language teaching to provide students with opportunities for language use. Though the textbooks prescribed for Yemeni schools are communicative-based textbooks, the majority of students still graduate from these schools with a very poor level in English generally and in oral communicative English particularly. This indicates that some problems are there and contribute negatively to students' achievement. These problems should be investigated and overcome in order to change the current situation. So this simple work is an attempt to delve into English language teaching and learning problems in these concerned schools as a pre-step towards suggesting some solutions and strategies for improving English language teaching and learning in future.

Though many studies have been conducted to investigate the problems of English language teaching and learning in Yemen, this study has been designed to replicate and validate some similar findings with a reference to Lahj governorate. It attempts to achieve the following:

- To survey major problems encountering EFL teaching and learning in Lahj primary and secondary schools.

- To recommend some solutions and strategies that may help in overcoming such problems and establishing a better communicative English language teaching.

\section{English language teaching in Yemen}

Republic Yemen is a country that was established for the first time in history in 1990 by a merged unification of two independent countries so-called People's Democratic Republic of Yemen (South Yemen) and Arab Republic of Yemen (North Yemen). As the two countries had different cultural backgrounds due to the different political scenarios they had undergone during the 19th and 20th centuries, the education and English language education too were also somehow different in the two countries. South Yemen was colonized by Great Britain during the period 1839 till 1967 and colonizers had introduced some education in English and some other subjects to some schools they were running in Aden colony. In the North, the situation was different as it was ruled by Imam who had deprived his people from education and made it limited to some prestigious families who work for him. To my information, there is no record for English language teaching in North Yemen before the revolution age 1962 .

After the independence of the South in 1967 and the end of Imam's reign in the North in 1962, the education began to take place officially in the two countries and the education systems faced some difficulties such as the lack of teachers and schools. Both education systems depended to a high extent on expatriate teachers, especially Arab and Indian, for teaching English and other subjects in their schools. In the 1970s, tertiary education appeared with establishment of Aden University (in the South) and Sana'a University (in the North) which contributed to the preparation of teachers for these schools and providing higher education to the two nations. 
With reference to English language education in the 1960s onwards in the two countries, English was compulsorily introduced by the Southern ministry of education from the 5th grade of the unity stage till the 4th grade of the secondary stage, with a total number of eight courses. In the North, English was introduced as a school subject in the 7th grade of the primary stage till the 3rd grade of the secondary school, with a total number of six courses. With the unification declaration in 1990s, the two education systems of the two states were merged too and English was placed as a compulsory subject to be taught within the curriculum of the public schools for six years, starting from the 7th grade of the primary school till the 3rd grade of the secondary school with a total number of six courses. Though the new born country had politically faced many difficulties from the first months of its birth and then undergone a civil war in 1994 which was viewed as an end of the unification agreement by the Southern State Authorities, the victorious North Yemen could keep the country forcibly unified with a unified education system. The ministry of education then introduced a new series of English courses in the 1990s called 'Crescent English course for Yemen' which could be described as communicative-based courses where language four skills are all emphasized (Ahmed \& Pawar, 2018).

Previous research in the field of teaching English as a second or foreign in Yemen and some other countries have showed many difficulties that EFL teaching and learning faces such as large classes, lack of qualified teachers, traditional teaching methodologies, students' low motivation to learn English as it is of no use outside classroom and inadequate learning facilities (Goss,1999; Wang, 2004; Fareh, 2010; Khan, 2012, Ahmed, 2018). This study will add to this field of research by providing a picture of the problems of English language teaching and learning in Yemen with a reference to Lahj Governorate.

\section{Methods}

This study is an exploratory study that aimed at surveying the problems of English language teaching and learning in Lahj primary and secondary schools from the viewpoints of EFL senior teachers and supervisors of Lahj governorate to suggest some remedial actions for overcoming such problems and improving EFL teaching and learning.

\subsection{Participants}

The sample of this study consists of 32 EFL senior teachers and supervisors of Lahj primary and secondary schools. Though there is a large number of schools with one or more teachers in each, this present study has only approached the viewpoints of 32 EFL senior teachers and supervisors who have good experience with English language teaching and learning in Lahj schools and have the interest to participate in the study.

\subsection{Research Instruments}

Two open questions, in the form of written interview, were submitted to many teachers via WhatsApp and Google Drive and responded by 32 senior EFL teachers and supervisors of Lahj primary and secondary schools. For getting more details about the finding, the researchers have also conducted WhatsApp's discussions with seven senior teachers and supervisors of the same sample. 


\subsection{Delimitations of the Study}

This study is limited to the public primary and secondary schools of Lahj governorate. It deals with the problems of English language teaching and learning in these schools from senior EFL teachers' and supervisors' perspectives. Due to war and financial circumstances that the country is undergoing, the researchers couldn't visit the concerned schools to conduct oral interviews with a larger number of teachers or to conduct some observations.

\section{Findings and Discussion}

This study aimed at investigating these two questions:

- What are the major problems of EFL teaching and learning in Lahj primary and secondary schools?

- What can be done to overcome such problems and improve English language teaching and learning in the concerned schools?

Based on the responses collected from 32 senior EFL teachers and supervisors, this research identified the following as the major problems and constraints of English language teaching and learning in Lahj primary and secondary schools.

\subsection{Large classes}

Majority of the teachers who participated in this study have identified large classes as one of the major problems encountering English language teaching and learning in their schools. Teachers have also argued in WhatsApp's discussions that large classes are a barrier to teaching and learning generally and to English language teaching and learning particularly. They mentioned that the number of students is increasing every year while there is no parallel increase in the infrastructure of schools. According to the participants' responses, the number of students in some of their classrooms exceeds 50 students. Such crowded classes are considered as a big challenge for EFL teachers as they face problems in class control and they also find it difficult to teach communicatively in such classes. Participants emphasized that it is so difficult to teach communicatively and to give students opportunities for practising English in a 40 minutes class where the number of students exceeds 50 , sitting crowdedly in a small room.

\subsection{Lack of teaching aids and materials}

Most of the participants have mentioned that there is a lack of teaching aids in most of their schools. They added that language laboratories are not available even in the major schools of the districts. Most of these schools don't have any auditory or visual teaching aids necessary for language teaching such as cassettes, recorders, computers, projectors...etc. The textbooks prescribed for teaching English in these schools are not provided to each student in some of these schools, so two or more students are usually requested to share the same textbook in some of these schools. Such a situation where teachers use only chalks and boards to teach English is considered as one of the problems encountering English language teaching and learning in the targeted schools. 


\subsection{Teachers' low proficiency in English and EFL teaching}

Many of the participants in this study have also pointed to teachers' low proficiency in English and their lack of awareness of CLT. They argued that in some schools, teachers of English are not English majors and have only limited grammatical and lexical competences. In the other hands, though the majority of EFL teachers may have a diploma or bachelor degree in English, they lack proficiency in spoken English and therfore most of their teaching revolves around teaching reading, vocabulary and grammar. The reason behind that is that many English teaching programs provided by the Yemeni faculties of Education don't prepare studentteachers well to be competent and qualified speakers of English. It happens to find some of the teachers who graduated from these programs perfect in written English but they can't communicate orally. Such a poor oral proficiency in the part of the teachers with their poor awareness of CLT approach will then be reflected in their teaching in these primary and secondary schools and constitute a constraint to language teaching and students' achievement.

\subsection{Time limits and lack of focus on communicative skills}

It has also been reported in participants' responses to the questions of this study that EFL teachers of Lahj schools focus more on completing the textbooks than on achieving students' proficiency in English. Teachers, due to time limit, their low .proficiency and lack of awareness of CLT techniques, rush to complete the textbooks prescribed by the ministry of education without paying much attention to students' proficiency level. The participants argued that oral communicative skills are ignored in the ministerial exams and the internal exams as well, as all exams focus on written aspects of English such as grammar, reading and writing while speaking and listening skills are mostly ignored. Such a way of teaching and testing in which spoken skills are ignored is considered as one of the factors contributing to students' poor English.

\subsection{Lack of exposure to English and the use of Arabic as a medium for teaching}

Participants have also mentioned that their environment doesn't provide exposure to English as English is not spoken outside the classroom. They have also added that Arabic is the medium for most English classes. Lack of exposure to English and the use of Arabic as a medium to teaching English hinder students' learning of English and makes English rather like a subject of study than being a means of communication. They emphasized that English should be given enough time to be taught as a means of communication and that both students and teachers should try to get in touch with English in and outside the classroom.

\subsection{Students' lack of motivation}

Participants have also reported that students' poor motivation to learn English has also been considered as one of the constraints of English language learning. Responses showed that due to the current economic situation and unemployment, some students think that there is no need to spend efforts in learning English as it will be of no use in their future professional life. They think that there is no place for them other than the recruitment in the army where English is not required. They emphasized that students' low motivation affects English language teaching and 
learning in their schools and that such low motivation is a result of the economic situation of the country, unemployment and cheating habits in ministerial exams.

\subsection{Late learning of English}

Some participants have also mentioned that Yemeni students usually start learning English within school curriculum at the 7th grade i.e. when they are approximately 13 years old and this age is viewed by them as late age for acquiring language. They think that English should be introduced from the early years of child's learning and should be given enough time to prepare students as users of English rather than learners of its rules.

\subsection{Interference between English and Arabic}

Participants have also mentioned that English is different from Arabic in so many aspects, especially in rules of grammar, sounds and pronunciations. Such interferences are viewed as sources of difficulties for learners as they need more time to master English.

Anyway, it seems that most of these problems are not only problems for English language teaching and learning in Lahj schools but can be generalized to many schools of the country and some other similar contexts. Similar studies which have been conducted in other contexts where English is taught as a foreign or second language had led to conclusions that referred to some of the problems found in this study (Fareh, 2010; Fatiloro, 2015; Al-Sohbani, 2015; Kalia, 2017; Ahmed, 2018; BinHady, 2018).

So far as solutions are concerned, participants' responses showed many suggestions that the ministry of education can apply to overcome the earliermentioned problems and improve English language teaching and learning. So this study, based on participants' inputs to the part of solutions and the researchers' experience in the field of teaching English as a foreign language in Yemen, recommends the following solutions for improving English language teaching and learning in Yemeni primary and secondary schools generally and the schools under this study in particular: 1- the number of students in the classroom should not exceed twenty-five students, 2- setting proficiency test for the teachers of English when recruiting EFL teachers, 3- organizing workshops and training for EFL school teachers to refresh their knowledge in English and to provide them with new trends in language teaching, 4- applying communicative language techniques such as roleplays, group work, pair work and cooperative learning in English classes, 5- provision of adequate auditory and visual teaching aids and materials such as cassettes, recorders, projectors, computers, textbooks, language laboratories if possible ...etc., 6- putting an end for cheating habits in the ministerial exams,7- establishing new teaching classrooms for some schools to suit the increasing numbers of students, 8sending those unqualified teachers who are currently teaching English in some schools though they are not English majors to English language education programs to qualify them in English language, 9- applying English as a compulsory subject within school curriculum from the early the first grate of the primary school and 10encouraging teachers to teach English as integrated skills where all skills are focused on. 


\section{Conclusion}

This work has investigated the major problems of English language teaching and learning in Lahj primary and secondary schools from the viewpoints of 32 senior EFL teachers and supervisors. This section will conclude the discussion by providing answers to the two major questions of the study:

a. What are the major problems of EFL teaching and learning in Lahj primary and secondary schools?

This study has concluded that large classes, lack of teaching aids, teachers' low proficiency in English, their limited experience with communicative language teaching, late beginning of learning English, lack of focus on communicative English, students' low motivation to learn English, Arabic medium in teaching English and interference between English and Arabic are viewed as the major problems that contribute negatively to EFL learning and teaching in Lahj governorate.

b. What can be done to overcome such problems and improve English language teaching and learning in the concerned schools?

This study has suggested the following for improving EFL teaching and learning in Lahj primary and secondary schools and in Yemen generally: 1- the number of students in the classroom should not exceed twenty-five students, 2- setting proficiency test for the teachers of English when recruiting EFL teachers, 3organizing workshops and training for EFL school teachers to refresh their knowledge in English and to provide them with new trends in language teaching. These training and workshops should be provided by native teachers of English or national experts in the field of ELT, 4- applying communicative language techniques such as role-plays, group work, pair work and cooperative learning in English classes, 5- provision of adequate auditory and visual teaching aids and materials such as cassettes, recorders, projectors, computers, textbooks, language laboratories if possible ...etc., 6- putting an end for cheating habits in the ministerial exams,7- establishing new teaching classrooms for some schools to suit the increasing numbers of students, 8- sending those unqualified teachers who are currently teaching English in some schools though they are not English majors to English language education programs to qualify them in English language 9- applying English as a compulsory subject within school curriculum from the early the first grade of the primary school and 10- encouraging teachers to teach English as integrated skills where all skills are focused on.

\section{References}

Ahmed, S. T. S. (2018). Challenges of English Language Teaching in Yemeni Primary and Secondary Schools. Academic paper, Grin Verlag, Germany. https://www.researchgate.net/publication/331135299 Challenges of English L anguage Teaching in Yemeni Primary and Secondary Schools.

Ahmed, S. T. S. \& Pawar, S. V. (2018). Communicative Competence in English as a Foreign Language: Its Meaning and the Pedagogical Considerations for its Development. The Creative Launcher, Vol.2 (4), 301-312. 
Al-Sohbani, Y. A. Y. (2015). An investigation of the reasons behind the weaknesses in English among public secondary school leavers. Journal of Teaching and Teacher Education, 4(01)

Bin-Hady, W. R. A. (2018). A Study of Novice Teachers' Challenges at Their Practical Teaching Phase. International Journal on Language, Research and Education Studies, 2(3). 333-345.

Canale, M., \& Swain, M. (1980). Theoretical bases of com-municative approaches to second language teaching and testing. Applied linguistics, 1(1), 1-47.

Cheng, L., \& Wang, H. (2004). Understanding professional challenges faced by Chinese teachers of English. TESL-EJ, 7(4), 1-14.

Crystal, D. (2012). English as a global language. Cambridge university press.

Fareh, S. (2010). Challenges of teaching English in the Arab world: Why can't EFL programs deliver as expected?. Procedia-Social and Behavioral Sciences, 2(2), 3600-3604.

Fatiloro, O. (2015). Tackling the challenges of teaching English language as second language (ESL) in Nigeria. IOSR Journal of Research \& Method in Education, 5, 26-30.

Goss, B. (1999). Challenges of Learning English in Japan. Intercultural Communication Studies. Vol. 8, 145-148.

Halliday, M. A. K. (1973). Explorations in the Functions of Language.

Hymes, D. (1972): On communicative competence. Sociolinguistics, 269-293.

Kalia, P. (2017). English language teaching in India: Trends and challenges. International Journal of Engineering Applied Sciences and Technology. Vol. 2, Issue 3, 33-37.

Khan, I. (2012): Teaching and learning of English: An exploratory study of difficulties and strategies. British Journal of Social Sciences, 76-93.

Littlewood, W. (1981). Communicative language teaching: An introduction. Cambridge University Press. 